\title{
Alexandra, Ribeiro, ESTABLISHING URBAN GARDENS ON VACANT LAND WHILE CONSIDERING INTERNATIONAL GOOD PRACTICES: A LEGAL CASE STUDY FROM PORTUGAL.
}

Alexandra Ribeiro, Universidade de Trás-os-Montes e Alto Douro (UTAD)Centre for Transdisciplinary Development Studies (CETRAD),), Portugal, alexandraafonsoribeiro@gmail.com, T - 00351919296527.

Raquel Carvalho, Universidade Católica Portuguesa,CEID - Centro de Estudos e Investigação em Direito,Faculdade de Direito-Escola do Porto,Portugal, rmcarvalho@porto.ucp.pt, T- 00351226196200

Lívia Madureira, Universidade de Trás-os-Montes e Alto Douro (UTAD), Centre for Transdisciplinary Development Studies (CETRAD), Portugal, Imadurei@utad.pt, T- 0035259350000

\begin{abstract}
There is a gap in most of the countries legal framework respecting its ability to connect vacant land and urban gardens. Hence research is needed to understand how regulation on vacant land might be designed to promote a more sustainable purpose to it. Urban gardens are a type of urban agriculture that could be potentiated by such. The aim of this paper is to show how that can be done through the Municipal Master Plans (MMP)legal and regulatory framework for the Portuguese case, by reviewing worldwide good practices on vacant land restorations for urban sustainable development. The paper comprises a literature review on good practices adopted in different countries regarding vacant lot restoration. The evaluation of good practices built on the achievement of three pillars of sustainability. Five Portuguese MMP were used, as empirical data, to support the design of a new legal and regulatory framework. The goal is to enhance the sustainable destination of vacant land by converting them into urban gardens.The analysis of these MMPs evidenced they disregard urban gardens as a tool to promote urban sustainability in spite of global trends to make urban territorial planning and management instruments greener. An additional outcome of this paper is to categorise different types of vacant land in the five municipalities under analysis according to their suitableness for urban garden conversion. The design of the legal framework enhancing of the conversion of vacant land into urban garden will contribute to the 2030 international agenda goals' achievement. The proposal would create an innovative legal framework in the case of Portugal, that could be replicated by other countries.
\end{abstract}

Key words: Municipal Master Plans; Sustainable Development Goals (SDG); Urban Areas sustainability; Urban gardens; Vacant land. Sustainability; Urban law. 


\section{Introduction}

Urban and territorial planning are useful instruments to achieve sustainable development in the three relevant dimensions: social development and inclusion, sustained economic growth and environmental protection and management (Campbell 2007; UN 2015; Goyburu and Montero 2018; Ultramari and Meister 2018).

Urban population grew from 746 million in 1950 (29.6\% of the world population) to 3.96 billion in 2015 (54\%). It is expected to reach 5.06 billion by 2030 (60\% of the world population)(UN 2015).

The exponential growth of population in cities created the need for developing instruments and mechanisms for sustainability driven urban and territorial planning, so that cities may grow on sustainable fashion pillar and ensure the quality of life of their populations. The growing urbanisation has become the 21st century challenge. In order to deal with this reality, different approaches regarding territorial planning have been tested and implemented worldwide. We intend to exploit the possibility of how the urban law instruments can be adjusted to address this challenge.

Vacant land in urban areas is perceived as a significant issue (Coleman 1982; Accordino and Johnson 2000; Gough and Accordino 2013) because it can disturb adequate urban and territorial planning. Urban vacant land is not favourable to sustainability. At the same time, it is a territorial environmental resource, providing opportunities for transformative and social ecological processes. (Németh and Langhorst 2014).

Within available literature, we find neither a definition in the law nor an evolution of the vacant land concept. However, to support the delimitation of a definition a review has been conducted on the concept of vacant land (Pagano and Bowman 2000; Németh and Langhorst 2014; Smith and Turner II 2017). Pagano and Bowman definition (2000 p. 2) was selected, their definition states that vacant land is "abandoned, destroyed, degraded and unused land, public or private, which exists in cities". Moreover, it is important to distinguish vacant land from related concepts such as common land and vacant buildings. In accordance with article 2, paragraph 1, of the Decree-Law from 2006 (Portuguese Government 2006) vacant building "it is considered vacant the urban building or the autonomous fraction unoccupied for over a year". With the publication of current Law from 2017 the concept of common land has been clarified and defined as "land with its integrating parts and equipment, owned and managed by local communities", in the terms referred to in paragraphs (i) to (iv) of Article 2 (a) of the Law from 2017 (Portuguese Parliament 2017). In Portugal common land with forest usage occupies approximately $14 \%$ of the global forest area in the continental territory, being organized in 115 forest perimeters distributed mainly by the mountains of the North and Centre of the country. It is thus clear that in Portugal the common lands are concentrated in rural areas, having a very small expression in urban ones, which are the subject of this paper.

There are a number of studies acknowledging that the reuse of vacant land represents an opportunity to the recovery of a wide range of urban areas (Pagano and Bowman 2000; Smith and Turner II 2017; Kim and Nowak 2018; Pothukuchi 2018). Greening vacant land could offer an interesting opportunity land use (Sanches and Pellegrino 2016). Nassauer and Raskin (2014), as well as Anderson and Minor (2017 p. 146), argue that "Vacant land restoration is best addressed by an interdisciplinary approach that combines economic, social and environmental needs and concerns into a holistic urban land use paradigm".

Urban gardens represent a key element to be considered in urban areas as they bring together three key aspects of sustainable development: social justice, economic development and environmental 
protection. They can contribute significantly for the sustainable development of any city (Viljoen 2005; Pinto et al 2011). Urban agriculture and urban gardens are very interesting tools to bring benefits to cities, such as strengthen urban food security, reducing urban poverty, improving the of urban-rural linkage, enhancing healthier urban environment and the urban biodiversity protection, along with strengthening of participatory culture.

Urban agriculture is a universal concept that is widely distributed across countless regions of the planet, both in developed and developing countries (Krikser et al. 2016). In this sense, urban policies should encourage the implementation of urban agriculture as a way to promote sustainable urban development (Tornaghi 2014). How urban planning system deals with the vacancy of urban land is a relevant research question (Trigo 2006). Since that greening vacant land represents an opportunity to the urban areas recovery, a relevant question is how legal instruments, like municipal master plans (MMP), can contribute to achieve this goal. As mentioned before, available research evidence shows that greening vacant land could be turned into a sustainable and interesting land use. However, there is not any research specifically focused on understanding how concepts such as urbanism, territorial planning and master plans can contribute to establish urban gardens on vacant land and by doing so to implement the sustainable development agenda at the municipal level. Hence, this paper addresses this gap by designing a proposal for a legal solution to encompass vacant land in municipal master plans enabling to accomplish urban sustainability goals.

In the following the paper is organised in eight sections. After this introduction, Section 2 describe its methodological approach. Therein the paper provides an overview of the Portuguese legal system and legal concepts are briefly discussed. Then the data used in the empirical analysis is introduced. A seventh section reviews the literature on urban gardens as an alternative use for vacant land. The final section presents and discusses the results and concludes the paper, offering a synthesis of the findings and their practical importance.

\section{Methodology}

The paper starts by identifying and describing both the international and Portuguese legal concepts of urbanism, territorial planning, environment, master plans and sustainable development and how they are interconnected. Empirical analysis is conducted through the analysis of MMPs from five municipalities of Porto conurbation (Porto and its four bordering municipalities of Matosinhos, Maia, Gondomar and Vila Nova de Gaia), located in the North of Portugal (see Fig. 1) respecting their references to urban agriculture and the uses considered for vacant land. Porto municipality was chosen because it was the first municipality to conduct an experience of urban gardens in Portugal with the project "Horta à Porta". This project was launched in July 2003 in municipality of Porto and has been expanded in the neighbourhood municipalities. The MMP and respective amendments were analysed and compared considering the Portuguese legal system.

A third task of this paper was to identify good practices of converting vacant land in urban gardens. For that purpose, a literature review was conducted considering good examples from other countries relating vacant land, master plans and urban gardens. The review was made using keywords such as: urban gardens; community gardens; vacant land. Examples of good practices were selected by selecting the case studies that comprise simultaneously the urban gardens, vacant land and the three pillars of sustainability. 


\section{Portuguese Legal System}

To better understand the scope of this paper, it is important to understand the legal system in Portugal. Urban law, environment and territorial planning are considered public law. It is a part of the juridical order, a complex system constituted by norms (principles and rules). Public Law is different from private law, because it grants public entities with authority powers and imposes special duties to private citizens, with the objective of pursuing public interests The hierarchy of sources of law in Portugal (Calvão et al 2018) is presented in the Fig. 1.

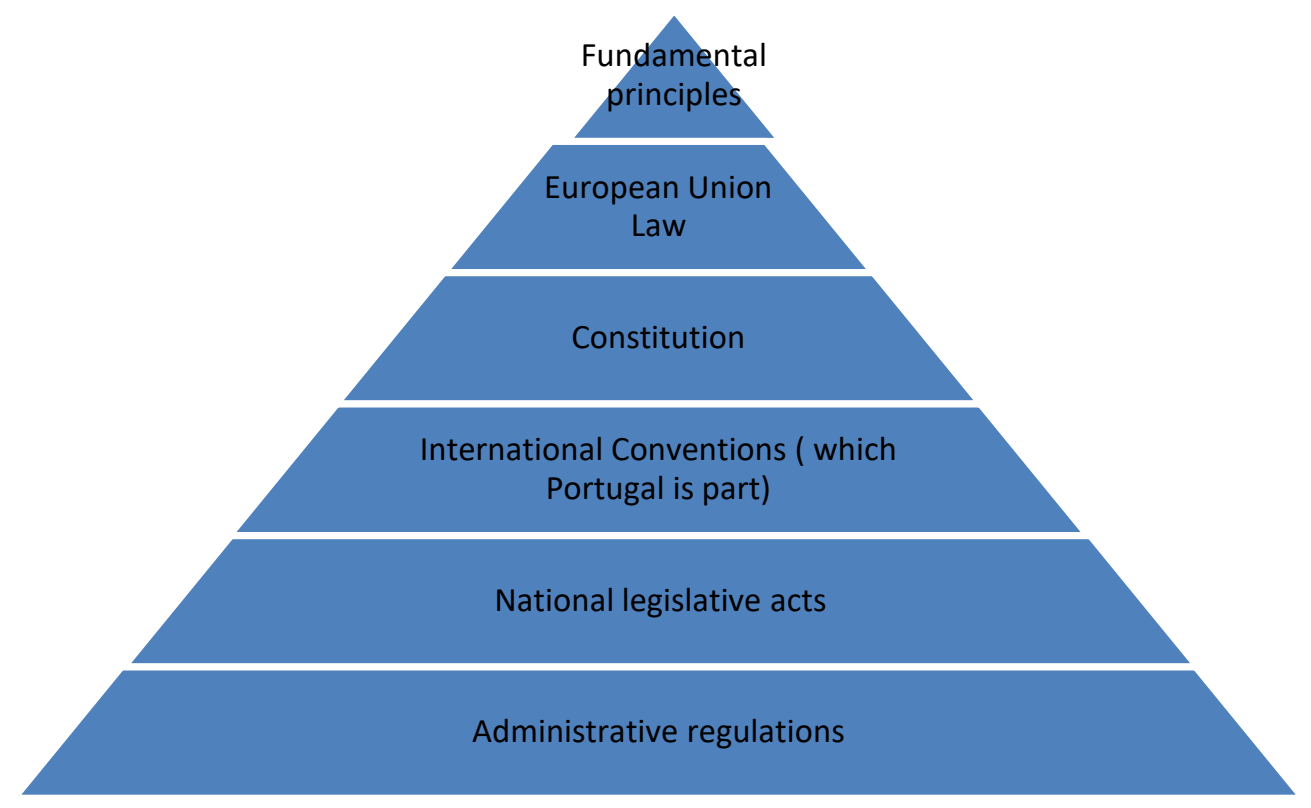

Fig. 1 Hierarchy of sources of law in Portugal

The national legislative acts are the Law (Portuguese Parliament), the Decree-Law (Government, as in Portugal, the Executive has extensive legislative powers) and Legislative Regional Decree (Regional Parliaments, within the matters related to Autonomous Regions).

Despite certain matters described in the articles 164 and 165, law and decree-law have equal legal force. Within the matter above mentioned, the law has reinforced value, as the Portuguese Parliament has the main Legislator.

The article 8 of the Constitucional Law from 1976 (Portuguese Parliament) establishes the rules concerning both the integration and position in the hierarchy of normative sources of the rules and principles of international law.

The administrative regulations are regulated by article 138 (3) of the Law from 2015 (Portuguese Government 2015) and are presented in the Fig.2. 


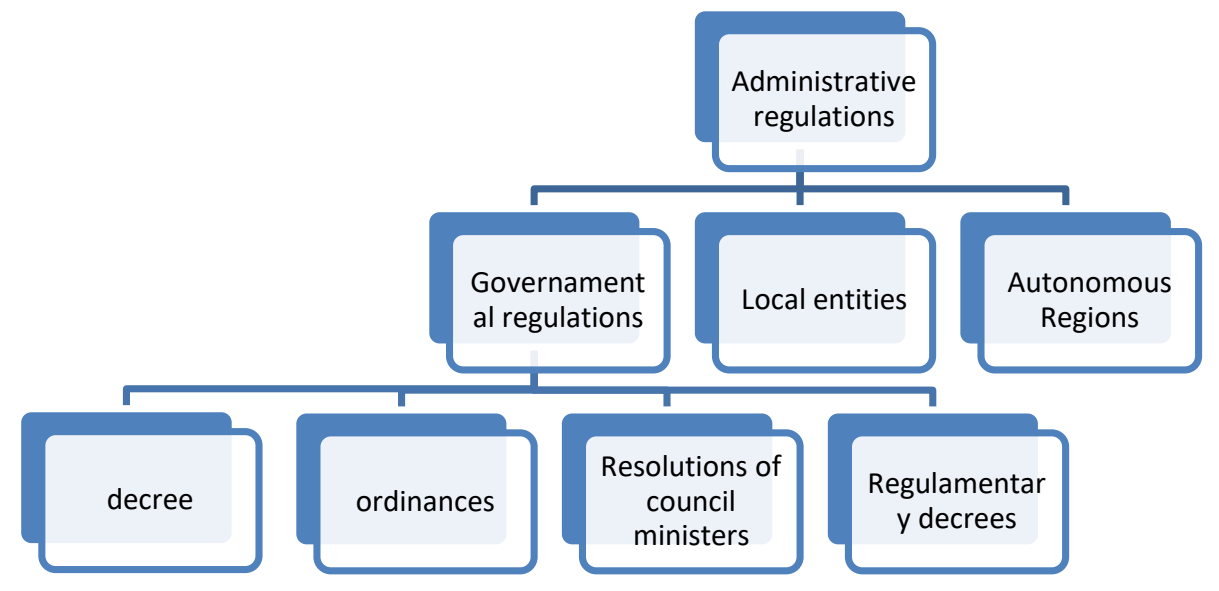

Fig 2 Legal framework of administrative regulations

For this paper, it is important to understand that the governmental regulations, despite being administrative regulations, could have normative content as the national legislative acts.

\section{Sustainable Development: The role of legal concepts of environment, urbanism, territorial planning and Instruments.}

\subsection{Sustainable Development: International and Portuguese Approach}

Sustainable development is a multidimensional and polysemic concept. Multidimensional because it enshrines economic, social and environmental aspects. Both their exact boundaries and practical application have been at the centre of many discussions over the last few decades across many academic and international institutional fields. The polysemy feature remains because no single meaning has yet been set, its nature ranging between a moral principle, a legal principle, and a legal rule (Saraiva 2012). Sustainable development is an important goal for both individual countries and the global community, and it is part of the object and purpose of many important international treaty regimes.

As expressed in the 1987 Brundtland Report (UN 1987), sustainable development can be defined as "development that meets the needs of the present without compromising the ability of future generations to meet their own needs'. According to Richard Ballhorn (2005), the conciseness of this most popular definition of sustainable development and its potential application to a wide range of policy fields makes it something very easy to be invoked in a range of meetings and documents. However, it turns out to be difficult when one aims to apply it on a sectoral basis or enshrine it into a legal text. Sustainable development is closely related to, and could be viewed as a core objective of, both national and international investment law and policy. The concept of sustainable development has steadily risen in status through the 1990's and into the 21st century and it was confirmed by the Johannesburg word summit as an inescapable development paradigm and such as a crucial element of the international agenda.

About its legal nature, in Portuguese legal system, sustainable development is one of the environmental principles, and it is also foreseen in public policy of land, land use planning and urbanism. Not to mention, its consideration on both social and economic policies. According to 
Canotilho (2010) although sustainable development is considered a structuring principle of constitutional law, it is, as other structuring rule of law, an open principle which neither materialises nor contains concrete solutions, accommodating several and different types of decisions. This is another polysemic dimension of sustainable development, now within the law field. Thus, Gomez (2017) upholds that the principle of sustainable development is an example of a false legal principle of environmental law, which is nothing more than a circumstantial and conjectural equation of the interests of environmental preservation and the interests of economic development.

In short, its content and scope are not yet consensual - whether within the national or the international legal order - as even the Brundtland Report does not substantiate its normative feature (Saraiva 2012).

\subsection{Environment, Urbanism and Territorial Planning: International approaches}

Considering the main public interests associated with urbanism, its diversity and territorial specificity, International Law, does not have to regulate in a homogeneous way, neither does urbanism have to emanate directives in this legal framework. Urbanism embody several public interests to pursue. This inner trait explains the absence and even the impossibility of a homogenous, accurate and definitive legal framework, from both national and international legal order. The territory is a complex system, comprising not only urbanised, rural or other spaces, but nature as a whole and the environment surrounding making.

In 1970, the CEMAT (European Conference of Territorial Planning Ministers) was established within the Council of Europe. It was one of the studies carried out by the CEMAT that led to the creation of the charter for Europe.

However, within the scope of the European Regional International Law framework and regarding territorial planning, we can find the European Regional/ Spatial Planning Charter of 1983). (CoE 1983)This is a relevant legal document as it defines the concept of territorial planning (Europa 2011) in its European dimension and its democratic, global, functional and prospective dimensions as well. The fundamental objectives of this Charter sets out goals of spatial planning the balanced socioeconomic development of regions, the improvement of the quality of life, the responsible management of natural resources and the protection of the environment, and the rational use of the territory, establishing the integration of the environmental component into the planning policies.

In Europe, the first major reference was the Green Paper on Urban Environment (European Commission 1990). Also the Alborg Charter (Alborg Charter 1994) calls for a generation of less sectoral urban policies that integrate the impacts of development on the environment.

It should also be made a reference to the Declaration of Ljubljana (COE 2003) on the territorial dimension of sustainable development adopted by the ministers responsible for regional planning at the 13th session of Europe conference of ministers responsible for regional planning (CEMAT). In order to promote sustainable development, spatial planning policies should reinforce their cross-sectoral dimension and vertical and horizontal governance and cooperation mechanisms to better evaluate the territorial impacts of all public policies and to strengthen synergies and the durability of results.

The United Nations adopted the International Guidelines on Decentralisation and the Strengthening of Local Authorities (2007), as well as the International Guidelines on Access to Basic Services for All (2009), which were previously adopted by the UN-Habitat Governing Council.

By means of the Resolution of the European Council of April 23, 2015, the United Nations adopted the international guidelines on urban and territorial planning (UNHS 2015). The International Guidelines on Urban and Territorial Planning are designed to support the future implementation of the ongoing 
Post- 2015 Development Agenda, and the New Urban Agenda of the third United Nations Conference on Housing and Sustainable Urban Development (habitat III) in 2016. These guidelines are important principles to take into account whenever establishing public policies.

\subsection{Environment, Urbanism and Territorial Planning: Portuguese Legal System}

As national level, the legal concepts of urbanism, territorial planning and environment are very closely related. As mentioned in previous chapter, Urbanism, environment and territorial planning are considered public law. Public law is autonomous from private law. It includes public legal persons, it grants them authority powers and it imposes special duties on them, with the objective of pursuing public interests. It is important the reference to public law because it is an increasing challenge for public entities to adequately answer the need of urban provisions directed towards the social dimension of the principle of sustainable development.

Environment is defined as rules and normative principles, as well as relevant decisions for the environment (Antunes 2008; Gomes 2017). Urban law is a different concept and it includes all the provisions concerning the occupation, the use and the transformation of the soil and in a restrictive perspective, referring to the rational ordering of the city (Correia 2008; Carvalho 2017).

The distinction between urbanism and territorial planning is difficult to substantiate, especially within this broad concept of urban law. The wide concept of Urban law deals with urban problems. It settles legal requirements concerning private building, it weights up the methods, the instruments and procedures that allow a dignified life for all who live and work in the city, therefore ensuring an adequate spatial planning of the territory (Oliveira 2002; Machado 2014). The distinction between territorial planning and urbanism can thus be the criterion of the range of the area of application or influence of the related instruments. The territorial planning has a wider range than urbanism. (Amaral 1994), but this is not enough to distinguish the concepts. There are several criteria in the doctrine that help distinguishing these two disciplines. Some authors (Oliveira 2017) adopt a mixed criterion, including the objectives pursued (if it is broader we refer to territorial planning if more restricted urbanism), the content (guidelines Broader we speak of spatial planning, true norms applied to the land of urbanism) and the legal effectiveness of the related instruments (if they link public and private we speak of urbanism if they link only audiences we speak of the planning of the territory).

Both concepts have been considered in Constitutional Law, in Articles 65 and 165 (Portuguese Parliament 1976). They arise in a complementary and distinct way and they have been treated differently. Article 165 foresees the parliament legislative power to pass the Law on Bases of spatial Planning and urbanism. Nonetheless, according to Article 65, the implementation of the housing policies relies upon the State. Those polices include in the general planning Territory plans, supporting by urbanization plans that ensure the existence of an adequate network of transport and social equipment.

Territorial planning and environment are also linked institutes. The environment received a large constitutional attention than urban law or spatial planning, because, as argued by article 66, everyone is entitled to an environment of human life, sound and ecologically balanced and the duty to defend it. Furthermore the environment does not have territorial limits as urbanism and territorial planning. Land use planning have its origin in the recognition that economic development could lead to considerable differences in the population territorial distribution, thus favouring goals such as the protection of the environment. Environmental law has a decisive influence on urban law since many urban law provisions, in particular urban plan provisions, are increasingly aimed at protecting the 
environment. The "Urban environmental law" results from the coexistence of the urban law with the environment law (Machado 2014).

At legislative level, a 2014 Law (Portuguese Parliament 2014) currently establishes the basis of land policy, land use planning and urbanism. The legislator established no provisions regarding the two concepts, of ensuring sustainable development and intra-and intergenerational solidarity, assuring the present and future quality of life and a balanced socio-economic development.

Among the most relevant issues to be considered in this paper, urban law includes the legal regime of territorial management instruments and, in particular, at the municipal level, the municipal master plan (Oliveira 2018).

\subsection{Portuguese Territorial Planning}

\subsubsection{Instruments}

It is now important to address territorial management instruments and how they relate to vacant land and urban gardens, as well as the underlying policies, thus drawing us to the purpose of this paper. The basic concern of Portuguese Urban Law has always been the growth of cities and not the potential of abandoned land (Bothe 2014). Territorial management instruments, namely municipal master plans, aim at real territorial conformation. Considering this goal, the classification and the requalification of the land (which are both translated into options of planning) are focused on the urban land, but not absenting the role of city planning concerning rural land.

Article 38 of the 2014 Law (Portuguese Parliament 2014) is adjusted by article 2 of a 2015 Law Decree (Portuguese Government 2015) herein stating that, land, territorial and urban planning policies are developed through territorial management instruments which act together and materialise in Programmes and Plans ${ }^{1}$ These laws have simplified and streamlined procedures, decentralized powers for municipalities, clarified the purpose, the content and the typology of municipal planning instruments.

Depending on the nature and territorial impact of the public interests pursued, the territorial management system is subdivided into national, regional, inter-municipal and municipal levels (Oliveira 2016). The policy of territorial planning and urbanism is based on the territorial planning system, which is organised in a framework of coordinated interaction in four areas.

\footnotetext{
1 Programs, establish the strategic framework for territorial development and its programmatic guidelines or defines the spatial incidence of national policies to be considered at each level of planning. On the other hand, Plans establish concrete options and actions in the planning and organization of the territory as well as define the use of land [paragraphs a) and b) of article (1) 38 of the 2014 Law in the version of the 2015 Law ].
} 


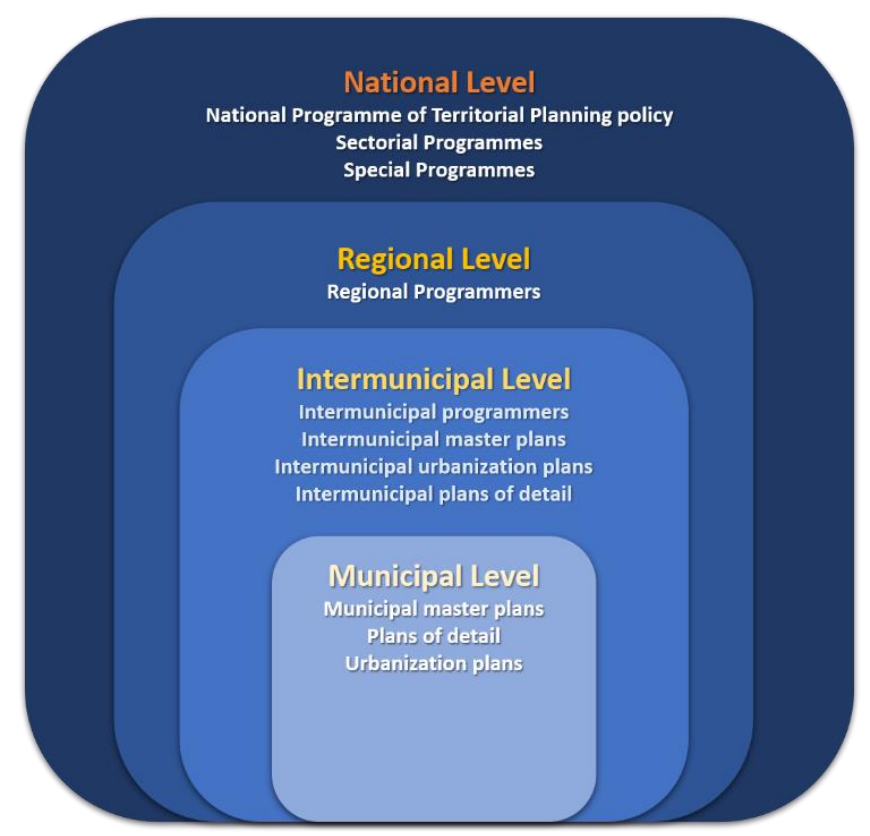

Fig. 3 Territorial planning and management system.

At municipal level, territorial plans, with their own options of local strategic development, set out the land usage regimes. Article 43 of the 2014 Law (Portuguese Parliament 2014) establishes the general bases of public policy of land, territorial planning and urban planning, and states that these plans are designated as municipal director plan, urbanization plan and detailed plan².

In particular, this new generation of municipal master plans has been providing a reinforcement of the strategic character according to the strategic objective 3 constant of the PNPOT (National Spatial Policy Programme) action program (2018).

These new municipal master plans are no longer a hard tool, and they now have the task of defining policies for territorial planning, urbanism and other urban policies. The municipal master plan may be detailed by others plans.

There is other territorial planning the National Agriculture Reserve which allows to define as the set of lands that present greater aptitude for agricultural activity in accordance with article 13 of the regulamentary decree from 2015 and law decree from 2012(Portuguese Government). It is a municipality duty to introduce in MMP the national agriculture reserve and the ecological reserve (not to determine them), and these reserves could be used to establish urban gardens in MMP.

\subsubsection{Classification and qualification of the land}

The classification and the qualification of the land was one of the subjects that underwent changes during the last Portuguese Urban reform. On the one hand, territorial plans become the only

2 The municipal master plan elaboration is mandatory, unless there is an inter-municipal master plan, and establishes, namely, the municipal territorial development strategy, the municipal territorial model, the options for locating and managing collective use equipment and the relations of interdependence with neighbouring municipalities. The urbanization plan develops and materializes the municipal director plan and structures land occupation and its exploitation, defining the location of infrastructures and the main collective equipment. The plan of detail develops and implements the municipal director plan, defining deployment and volumetric) of buildings, the form and organization of collective use spaces and the layout of infrastructures (no.3.4 and 5 of article 43 ). 
instruments capable of determining the classification and the qualification of land usage, as well as their respective execution and programming, thus having a strategic content in the territorial management system, (UNHS 2018), on the other hand, the 2014 Law (Portuguese Parliament 2014) currently classifies and qualifies the land into only two categories, urban land and rustic land ${ }^{3}$.

The law of territorial management instruments contains a new definition of urban land and the municipal master plans must make a new delimitation and revise it within 5 years (up to 2020). Planning for sustainable use of land resources towards a new approach.

This new twofold distinction differs from the previous classification of rural, urban and urbanizable land. Thus, it gives more room to classify certain soils as rustic, previously classified of urbanizables that were years in the expectation of becoming urbanized. This discouraged the economic activity inherent to the rural usage and constituted a total economic waste of the land. This new situation allows for rustic land other more sustainable purposes in their economic, social and environmental aspects and being effectively and clearly utilized in their Municipal Master Plans (PDM )s areas for urban agriculture (Oliveira 2015).

Having described the regulatory framework of the territorial management system, its instruments and the classification of land, it will be assessed where vacant land can be placed therein.

Vacant land, understood here as abandoned, destroyed, degraded and unused land, public or private, which exists in cities, is not foreseen in any direct legal provisions, but only a few references throughout the legislative text, namely as

a) one of the objectives of territorial management [ Article 37, paragraphs d) and e) of the 2014 Law (Portuguese Parliament 2014)];

b) one of the duties of owners, minimising the level of exposure to collective risks [cf. Article 14 (2) of the 2014 Law from 2014 (Portuguese Parliament 2014)];

c) Article 12 (2) (e) of 2015 Law (Portuguese Parliament 2015), states that territorial plans identify territorial resources relevant to nature conservation and biodiversity, and

d) Article 16 of 2015 Law (Portuguese Parliament 2015) also seems indirectly to refer to rural buildings as key areas for protection and enhancement environment, setting soil use conditions to ensure the well-being of people.

Nothing else is set regarding the use of unused, degraded, abandoned and/or destroyed urban or rural land.

But this issue may be addressed at the municipal level, namely in the Municipal Master Plan (MMP) and Detail Plan (DP). In accordance with the provisions of Article 103 (2) a) of 2015 Law (Portuguese Parliament 2015), one of the specific modalities of the detail plan is the intervention plan in the rustic space.

\footnotetext{
3 Pursuant to the provisions of Article 10, "rural land" means "the soil which, by virtue of its recognized ability, is intended, in particular, for agriculture, livestock breeding, forestry, conservation, valorisation and exploitation of natural, geological or energetic resources, as well as that which is intended for natural, cultural, tourism, recreational and leisure spaces or risk protection, even if occupied by infrastructure, and that which is not classified as urban "and by "urban land" that which is totally or partially urbanized or built and, as such, attached in territorial planning for urbanization or edification.", concepts embodied in article 71.
} 
In times of change and challenges, urban management models have to be adjusted to the needs and must at the same time guarantee the economic and financial sustainability of the territorial occupation (Carvalho and Oliveira 2016). Vacant land restoration is best addressed by an interdisciplinary approach that combines economic, social and environmental needs and concerns into a holistic urban land use paradigm (Anderson and Minor 2017).

The following chapter explains how to take advantage of this opening of the law, granted by the most recent legislative changes to the instruments of territorial management, for a sustainable development perspective to enable urban agriculture to flourish in the vacant land of cities. This indication of contributes to the targets set out in the 11th Sustainable Development Goal (UN 2015) aiming at make cities and human settlements inclusive, safe, resilient and sustainable ${ }^{4}$ by giving vacant land a sustainable purpose by the promotion of urban gardens.

\section{Portuguese Case Study}

This section provides an overview of the municipal master plans' contents. It includes the distinction between urban and rural land and the references to urban agriculture. We intend to identify at what extent reference is made to urban agriculture in the MMP from Porto, Matosinhos, Maia, Gondomar e Vila Nova de Gaia.

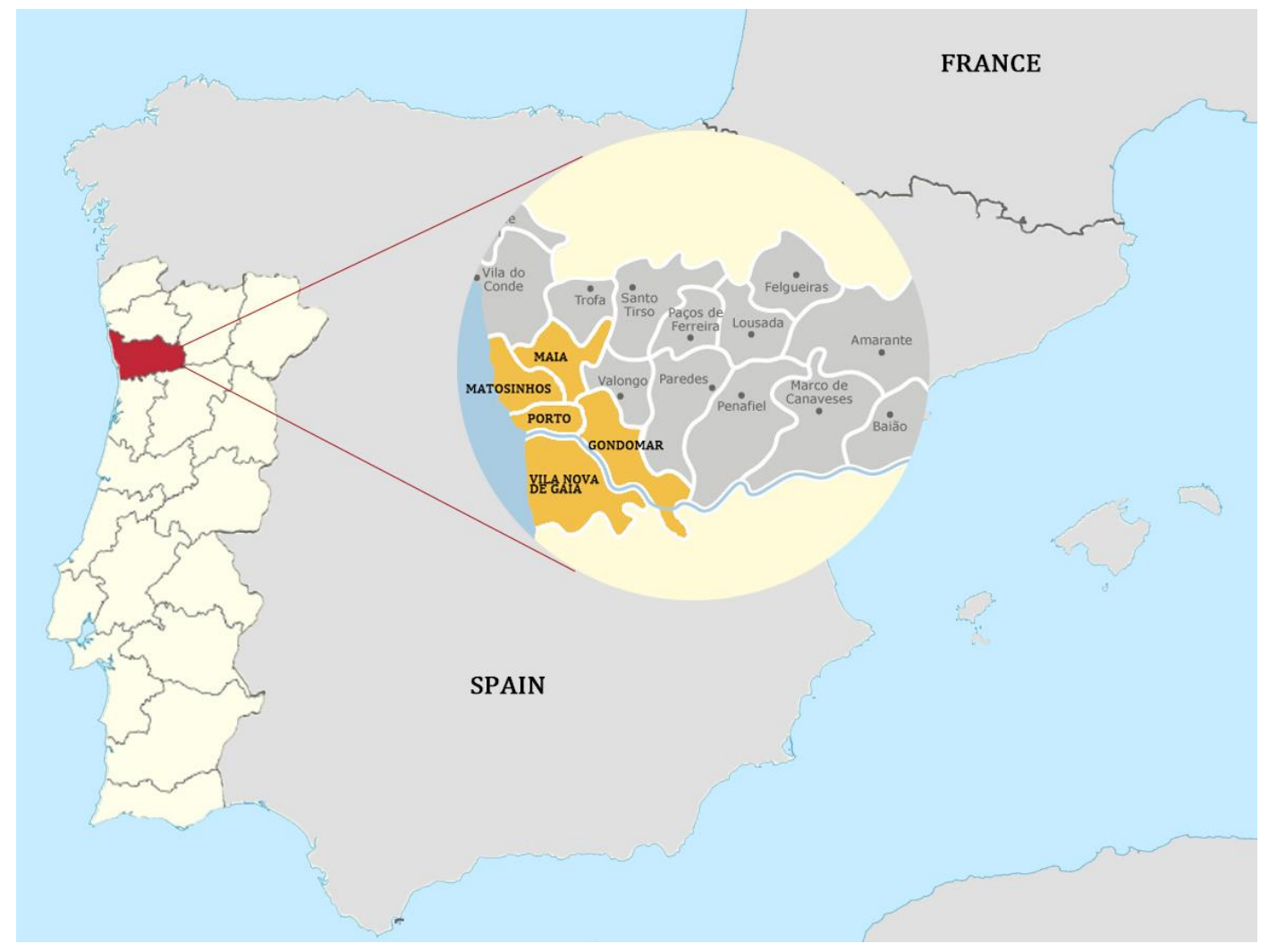

Fig. 4 Porto and 4 boundaries municipalities

\footnotetext{
${ }^{4}$ https://sustainabledevelopment.un.org/\#
} 
Table 1 Comparison between the five MMP (Municipal Master Plans)

\begin{tabular}{|c|c|c|c|c|c|}
\hline & PDM (MPP) & $\begin{array}{l}\text { Distinction between } \\
\text { urban and rural land }\end{array}$ & $\begin{array}{l}\text { Land references for urban } \\
\text { agriculture purposes }\end{array}$ & $\begin{array}{l}\text { Other } \\
\text { regulations }\end{array}$ & $\begin{array}{c}\text { Regulatory } \\
\text { decree } n . ? \\
15 / 2015 \text { of } 19 \\
\text { august }\end{array}$ \\
\hline Porto & $\begin{array}{l}\text { Notice } n .014332 \\
\text { of October } 25 \text { th, } \\
2012\end{array}$ & $\begin{array}{l}\text { Classification of land as urban } \\
\text { (Article 7). No classification } \\
\text { as rural land. }\end{array}$ & $\begin{array}{l}\text { Article } 8 \text { (2) paragraph a) Land } \\
\text { Belonging to Ecological Structure; b) } \\
\text { Green Area of Public Use. Article } 38 \\
\text { paragraph c) Mixed-use Urban Green } \\
\text { Areas. Article } 39 \text { paragraph c) Private } \\
\text { Green Area. Article } 40 \text { paragraph d) } \\
\text { Green Area for Space-channel Framing. } \\
\text { (Article 41). }\end{array}$ & $\begin{array}{l}\text { Pea Park } \\
\text { enlargment }\end{array}$ & $\begin{array}{l}\text { Articles } 7,13 \text { and } 14 \\
\text { and Article } 25 \text { (1) d) }\end{array}$ \\
\hline Matosinhos & $\begin{array}{l}\text { Order n. } 92 / 92 \text { of } \\
\text { September } 3 \text { rd; } \\
\text { Notice } n .9 \\
3139 / 2014 \text { of } \\
\text { February } 28 \text { th }\end{array}$ & & Article 41 and 42 Green Area & & \\
\hline Maia & $\begin{array}{l}\text { Notice } n .9 \\
9751 / 2013 \text { of July } \\
\text { 30th }\end{array}$ & $\begin{array}{l}\text { Article } 13 \text { Classification of } \\
\text { Urban Land and Rural Land. } \\
\text { Article } 14 \text { Qualification of } \\
\text { Rural Land a) Agricultural } \\
\text { Space. Article } 15 \\
\text { Qualification of Urban Land } \\
\text { a) e) Green Spaces. }\end{array}$ & $\begin{array}{l}\text { Article } 33 \text { Agricultural Spaces, Article } \\
83 \text { Green Spaces a) Green Spaces of } \\
\text { Public Use and d) Mixed-use Urban } \\
\text { Green Spaces. }\end{array}$ & & $\begin{array}{l}\text { Article } 7 \text { and Article } \\
17 \text { a) and Article } 25 \\
\text { (1) d) }\end{array}$ \\
\hline Gondomar & $\begin{array}{l}\text { Notice } \mathrm{n} \text { - } \\
13057 / 2015 \text { of } \\
\text { November } 9 \text { th }\end{array}$ & $\begin{array}{l}\text { Article } 16 \text { Qualification of } \\
\text { Land; Article } 17 \text { and Article } \\
18 \text { Rural and Urban Land. }\end{array}$ & $\begin{array}{l}\text { Article } 30 \text { Agricultural Spaces; Article } \\
60 \text { Green Spaces a) green spaces of } \\
\text { public use }\end{array}$ & & $\begin{array}{l}\text { Article } 7 \text { and Article } \\
17 \text { a) and Article } 25 \\
\text { (1) d) }\end{array}$ \\
\hline $\begin{array}{l}\text { Vila Nova de } \\
\text { Gaia }\end{array}$ & $\begin{array}{l}\text { Notice } \mathrm{n}- \\
14327 / 2009 \text { of } \\
\text { August } 12 \text { th }\end{array}$ & $\begin{array}{l}\text { Article } 8 \text { Rural and Urban } \\
\text { Land; Articles 22, } 35 \text { e } 83 \text {. }\end{array}$ & Articles $22,83,84,85$ and 86 & $\begin{array}{l}\text { Regulation of } \\
\text { urban gardens }\end{array}$ & $\begin{array}{l}\text { Article } 7 \text { and Article } \\
17 \text { a) and Article } 25 \\
\text { (1) d) }\end{array}$ \\
\hline
\end{tabular}

Table 1 is based on the referred Article 94 of the Law decree from 2015 (Portuguese Government 2015), which addresses the national territorial information system and the information it contains concerning municipal master plans, and respective information on the internet sites of each of the referred municipalities (Guedes 2015). This project began in July 2003 in municipality of Porto and it was expanded to their four bordering municipalities.

As the table shows, it turns out that the Gondomar, Vila Nova de Gaia and Maia' s municipal master plans distinguish between rural and urban land, exception to Matosinhos and Porto (Porto Government 2012), which consider all the land as urban. In Matosinhos, the distinction is however described in the Plan of Detail. The reason why there is no explicit reference in this MMP is that the municipality of Matosinhos has approved a Municipal Regulation of land occupation.

In the same way, apart from Matosinhos' MMP, all the remaining plans have provisions regarding the destination of the land for urban agriculture purposes, either rural land expressly used for agricultural purposes, or urban land. Still, a small reference is made in accordance with article 74 of the decree law from 2015. This last regulation establishes the criteria for classification and reclassification of soil, as well as the criteria of qualification and categories of rural and urban soil according to the dominant use. There is still plenty of room for an adequate and sustainable prediction of the use of vacant land for urban gardens and even the prediction of urban or rural land for urban agriculture and the use of vacant land for urban agriculture. Only the legally foreseen designation of green spaces or mixed green areas could be found. And even these green spaces, absolutely vital for a sustainable city, are not evidenced in the planning instruments (Sousa and Madureira 2017). None of the master plans analysed contained any contrary provision to the law. The mere absence of provisions has no legal consequences whenever the law gives room to municipal bodies to decide. If there were provisions against or 
contrary to imperative legal provisions, the MMP could be declared null according to article 96 (3) or suspended as result of article 126 both from the decree Law from 2015 (Portuguese Government 2015)

In accordance with article 14 of the Decree Law from 2015 (Portuguese Parliament 2015), programmes and territorial plans identify the areas committed to agricultural uses applying the classification of the regulatory decree from 2015 (Portuguese Government 2015). As a way of compensating these discontents, during the planning of countless Portuguese cities, green plans were developed, as supporting documents for the municipal directors' plans. As an example Quintas (2014) designates the green Plan of Lisbon, which was developed on 1997, as a complement to the respective MMP.

No priority has been given to the integration of agricultural land (related with rural land) in territorial and urban planning, as it has not yet acquired true importance, always being a second-ranked action in the face of its economic devaluation (Fadigas 2017).

Vila Nova de Gaia Municipality has published in 2018 a Regulation on urban gardens (Vila Nova de Gaia Municipality Government 2018) Regulation No. 442/2018, of July 19th, approving the municipal rules of their urban gardens' network. According to Saraiva (2011), such urbanization plans and detailed plans at municipal level are useful to slow down real estate expansion and assure the creation of green spaces in the urban centres. These plans are based on the National Plan of Territorial Planning Policystrategy (PNPOT-strategy), which considers the synergies of urban and rural spaces fundamental and points to the importance that municipal planning instruments consider areas that promote these synergies. The plans take in consideration a resolution of Council of Ministers from Portuguese Government 2015, which approves the "sustainable Cities" strategy that provides in paragraphs 2.5 and 2.9 evidences of both, the integration of rural and urban land in cities and the provisions regarding land's use.

Urban gardens translate a spontaneous way of using the interstitial spaces of cities (Foo et al. 2014). According to Guerreiro (2008) the interstitial spaces are the unbuilt spaces resulting from the disposition and adjunct of the buildings. In architecture, these spaces are called negative or empty, such as hidden streets.

\section{Urban gardens as urban green spaces}

Although not explicitly mentioned, among the various types of urban green spaces, urban gardens are the typology that can present greater benefits (Celata and Coletti 2018; Wong et al 2018). As argued by Telles (1996), it becomes essential that urban interferes in rural land and re-models the rurality of the city. In this line, the gardens that the citizens seek are not static (just sitting on the bench), but dynamic and allow to work on the gardens while breathing deeply (Madaleno 2001; Barthel at al 2013).

The reasons that lead individuals and communities to participate in urban gardens are various. Armstrong (2000) lists several reasons, such as access to fresh food, taste for nature and health benefits, breakdown of social barriers and reduction of crime, among others.

The role of urban gardens in social cohesion is also noticeable by the evidence that collective urban gardens experiences promote inter-personal interaction, facilitate integration of newcomers and help raising the sense of community and neighbourhood (Shaw et al. 2016; Sotelo 2017). They also appear to help linking economic and other dimensions of sustainability by providing households and 
communities the opportunity to value food variety and food safety along with the cost and effort of producing food in an environmentally-sound way

In this sense, as stated by Tornaghi (2014), urban policies should encourage the implementation of urban agriculture as a way to promote sustainable urban development, an argument that is corroborated by other authors (e.g., Barthel et al 2013; Moragues-Faus and Morgan 2015). Community gardens and urban gardens can play an important role in promoting health, social inclusion, civic participation and sustainable living practices in urban environments (Turner et al 2010) and can also serve as integration catalysts. According to Sotelo (2017), in certain more deprived or immigrant communities, urban gardens act as alternative households and food production sites where children are nourished and protected, where, as stated by Baeten (2016), the sick are cured, and as places of conviviality for moments of leisure, socialization and quiet individual reflection.

In this sense, urban gardens are life quality enhancers, contributing significantly to making people feel happier, changing and improving their daily habits (Costa et al 2017; Moreira et al 2017).

Urban gardens show a multidimensional importance encompassing economic, social (food security, health promotion and welfare), environmental, pedagogical and aesthetical aspects (Carlsson et al 2016; Truong et al 2016). As reinforced by Pereira (2017), the concept of the new wave of urban gardens and urban agriculture appears to be associated with a multifunctional character, including leisure and recreation, food supply, restoration and/or recovery of degraded land, as well as social cohesion and a sense of belonging, intangible benefits (Barthel et al 2013; Gonçalves 2014).

Some studies (e.g., Truong et al 2016; Carlsson et al 2016) argue that experiences with nature since childhood influence the adoption of more sustainable behaviours, particularly in relation to food. It is intended that fruits and vegetables are cultivated in areas around or near the school, providing a source of basic small-scale foods, as well as other activities (Sottile et al 2016) In particular, a study by Carlsson et al (2016) points to the fact that these gardens can facilitate positive links between the school and the home, and, at the same time, allow the community a better understanding of the food ingested and greater civic responsibility.

Despite all the benefits of urban gardens outlines in previous section, there is still a deficient legal provision of urban gardens in the territorial management instruments.

\section{Converting vacant land into urban gardens: Identifying best practices in Europe and worldwide}

Already in 2000 a study by Schukoske (2000) shows that legislation often does not promote the temporal sustainability and successful use of vacant land. The study argues that urban gardening in United States has developed as a viable alternative to vacancy land. Numerous studies have proven that the use of vacant land is a gain to communities and the environment and should be increased (McClintock et al 2013; Draus et al 2013; Sanches and Pellegrino 2016; Smith and Turner II 2017). According to Newman et al. (2016) "Sustainable growth approaches such as smart growth, the strategic reuse and infill of urban vacant land can represent a major opportunity for encouraging greater density and reducing suburban development". The transformation of vacant lands into green spaces, including the urban gardens, is envisaged with growing interest by urban land planning policies (e.g. Park and Ciorici, 2013; Sanches and Pellegrino 2016; Newman and Smith 2017) Anderson and 
Minor (2017) highlight that these are the type of initiatives that enhance the sustainable development of cities and urban conurbations, in line with the Brundtland report of 1987 (UN 1987).

Urban gardens and vacant lands are increasingly at the convergence of a variety of urban policies and planning issues in North American, European and Australian large and medium cities (Drake and Lawson 2013). Vacant lots are becoming incorporated into the urban ecological paradigm in European cities (Anderson and Minor 2017). Since one of the objectives of this paper is to identify good practices of converting vacant land in urban gardens built on a literature review of available evidence, this section presents the results of that.

Trying to identify the good practices in Europe and worldwide, a literature review of case studies was made using a systematic search on web of science. The review was prepared using some keywords such as: urban gardens; community gardens; vacant land. Case studies comprising simultaneously the terms of urban gardens, vacant land and the three pillars of sustainability were selected and analysed in more detail. The objective was to gather evidence that an underexplored resource for ecological, social and economic benefits in cities is the reuse of vacant land. Some case studies were selected and its analysis allowed for the identification of three good practices:

1. Having an updated inventory of public and private vacant land. Newman et al. (2016) present the results of a US country level survey on urban land vacancy in large American cities. This survey was adapted from Pegano and Bowman survey instrument for online use. These inventories show how the ratio of vacant land to city land area has increased along the time and why that has happened. Hence, they allow to evaluate the effectiveness of different urban land planning policies of US large cities. The importance of having an updated vacant land inventory is also highlighted by Trigo (2006) in a study aiming at understanding how the urban planning system deals with the vacancy of urban land in the cities of London and Madrid. This author concludes that there is a lack of primary data sources on the nature and extent of vacant land, that vacant land is used in a broad sense to define a wide variety of empty spaces, and that there is no consensus about the reasons and conditions of vacancy.

To achieve an updated inventory of public and private vacant land it is necessary to find the most adequate theoretical and holistic framework (Trigo 2006). There are some good examples in the literature (Accordino and Johnson 2000; McClintock et al. 2013 ; Newman et al. 2016). Tackling the existence of urban vacant land is a matter of great importance for any sustainable agenda.

2. Integrating urban garden in the cities master plans. According to Hou and Grohmann (2018), in large cities such as Washington, DC or Oakland, CA, community gardens have been considered in the cities comprehensive or general plans, and in Seoul (South Korea), the Municipal Government put forward an Urban Agriculture Master Plan in 2012 that included community gardens as a major component. Using the city of Seattle as case study, Hou and Grohmann (2018) defend the integration of community gardens that were originally vacant land into the city urban park, as a way of preventing these gardens from being converted back to vacant land. The authors in their study examine lessons and challenges of integrating urban gardens in major urban parks. Another study by Németh and Langhorst (2014) focused on the temporary uses of vacant land. In their study Németh and Langhorts adopt a definition derived from Bishop and Williams that argues that temporary cannot be based on the nature of the use, but rather the intention of the user, developer or planner that the use should be 
temporary (Németh and Langhorst 2014). They argue economic, social, political and ecological advantages of the temporary use and conclude that a temporary use model might just serve as an instrument to encourage more realistic approaches to urban transformation. They argue that any attempt to implement temporary uses needs to be grounded in the specific conditions and process of a particular location at a particular time. Reinforcing this way, the idea of the need for a legal framework to integrate vacant land and allow its permanent conversion to urban gardens. In survey, city land policies was deemed important as methods for decreasing vacancy.

3. Developing a specific legal framework to promote urban gardens. Schukoske (2000) reviews the legal framework of urban gardens in US. This author proposes a model for local governments to implement urban gardens programmes, entailing elements such as:

- assigning the duty of inventorying vacant public lots and vacant private lots,

- authorising contracting with private landowners for lease of vacant lots,

- authorising the use of municipal land for minimum terms long enough to elicit commitment by gardeners (such as five years), and,

- providing gardeners tools, water, compost, liability insurance, favourable tax treatment.

\section{Discussion and introducing a proposal to integrate urban gardens in to Portuguese municipal master plans as way to reuse vacant land}

As a result, despite all the benefits of urban gardens there is still an incipient indirect reference of urban gardens in the Portuguese territorial management instruments. And if MMP does not include the urban gardens as a priority and still makes a small reference to urban agriculture, despite all international inputs to transform their territorial instruments into greener ones, maybe the reuse of vacant land could be a good answer for this lack.

Portugal could, at first, considering the legal system, the actual state of territorial instruments and the small influence from international territorial planning, the good practices implement worldwide and the success of some legal instruments that were used in other countries, establish both the duty of inventory of vacant land and the duty to disclose information readily accessible to the public. This last duty would be similar to a land stock exchange. That would allow to create a framework for identifying and designating vacant lots that are better suitable for either developmental or ecological purposes (Newman et al. 2017). To achieve this goal, we purpose to start tackling the existence of vacant land in Portuguese cities and trying to identify the type of vacant land. Thus, it would be necessary to conduct a national survey on vacant Portuguese land (in the sense of Newman et al. 2016), considering the factors and determinants contained in the previously presented literature review (e.g. Park and Ciorici 2013; Foo et al. 2014; Newman et al. 2016). This survey intents to identify the urban vacant land typology (if derelict; unexplored; abandoned; inhabitable...) the ability of the soil for agriculture purposes (if is contemned or not) and ownership (Sanches and Pellegrino 2016). Therefore could be important demonstrate if vacant land is close to commercial or residential areas (Park and Ciorici 2013), which are the community quality factors most affected by vacant land (Accordino and Johnson 2000) or if vacant land is increasing or decreasing (Newman et al 2016).

Secondly, as we seen in the Portuguese case study, urban gardens are not included, at least in a relevant way, in city master plans. The sustainable use of urban gardens in urban spaces and the 
identification of vacant land suitable for urban agriculture use, at least for a temporary period of time, is a possible solution, using the data that would result from the survey mentioned above.

Urban agriculture would benefit from legal regulation and its potential inclusion in municipal master plans (MMP) in the broader context of coherent local public policies, including on the municipal master plan or in the plan of detail in writing a prevision of:

A) the sustainable use of urban gardens in urban spaces based on principles of sustainable development, considering that land is one of the scarcest and valuable resource in municipalities. European Commission has pointed out that sustainability should not only focus on sustainability growth but also addressing the existence of resources in a more effective way and

B) The assessment of land that can be considered vacant land usable for urban gardens purpose, supported by a categorisation of vacant land existent in municipalities, build on the above mentioned inventory.

One of the most effective ways of building a green structure and urban gardens is to adopt a more integrated approach to land planning. This can be achieved through territorial planning at municipal level.

\section{Concluding remarks}

In conclusion, vacant land is a worldwide important issue because it continues to be seen as a problem that must be "fixed" and as a resource that can provide opportunities for transformative social and ecological processes. It has a particular meaning within the law. The reuse of vacant land depend and could benefit from public policies, territorial planning instruments, provisions in the different legal systems and its implementation.

Although the Portuguese legal framework already defines sustainability as a goal and intergenerational solidarity and as a principle of territorial planning and urban planning policy, its application has been far from implemented, given the various interests that determine the use of the land in urban space, encompassing conflictual economic interests and social policies.

The legislator must acknowledge that urban gardens are consistent with policies such as the promotion of public health and well-being, the environment, economic development, education, employment, and tourism. Promoting such policies through urban gardens requires regulation that provide their real implementation, as well as the technical and material support.

Furthermore, since cities are the largest consumers of natural resources and the largest producers of pollution and waste, it emerges as evidence that most of the obstacles to global environmental sustainability will have to be resolved at the urban level (Madureira 2005).

Bearing in mind good international practices and the findings in the Portuguese case study, we can conclude that in the Portuguese case we are still far from assigning a sustainable use of vacant land. It is imperative to do an inventory of vacant land and to establish legally the urban gardens in Portuguese MMP. These proposals could help to achieve sustainability of Portuguese municipalities. Ultimately, Portugal could be an example on how to achieve the 2030 agenda. Therefore, we propose to integrate the urban gardens in the Portuguese MMP as a way to take advantage of the vacant land. 


\section{REFERENCES}

Accordino J, Gary J (2000) Adressing the Vacant and Proprety Problem. Journal of Urban Affairs 22(3): 301-15.

Alborg Charter 1994. http://portal.uur.cz/pdf/aalborg-charter-1994.pdf

Amaral D (1994) Ordenamento do território, Urbanismo e Ambiente: Objeto, Autonomia e distinções. Revista Juridica do Urbanismo e do Ambiente: 11-22. (territorial planning, urbanism and environment: Object, autonomy and distinctions)

Anderson E, Minor E (2017) Vacant Lots: An Underexplored Resource for Ecological and Social Benefits in Cities. Urban Forestry \& Urban Greening 21: 146-52.

Antunes L, (2008).Direito Público Do Ambiente. Almedina. Coimbra. (Public environmental law)

Armstrong D (2000) A survey of community gardens in upstate New York: Implications for health promotion and community development. Health \& Place: 319-27.

Baeten, M (2016) Primeiro Colóquio Nacional de Horticultura Social e Terapêutica Social. Agriculture: Funding in the Netherlands.

Ballhorn, R (2005) The Role of Government and Policy in Sustainable Development. https://www.mcgill.ca/mjsdl/files/mjsdl/ballhorn vol1.pdf

Barthel S, Parker J, Ernstson H (2013) Food and Green Space in Cities: A Resilience Lens on Gardens and Urban Environmental Movements. Urban Studies Journal Limited: 1-18

Bothe A (2014) Direito do Urbanismo, do Ordenamento do Território e dos Solos em Portugal e na Alemanha. JURISMAT: 289-319. (Urbanism law, territorial and land planning in Portugal and Germany)

Calvão F, Campos M, Botelho C (2018) Introdução Ao Direito Público, Almedina. Coimbra. ( Public law introduction).

Campbell S (2007). Green Cities, Growing Cities. Journal of the American Planning Association 62(3): 296-312

Canotilho G (2010) O princípio da sustentabilidade como Princípio estruturante do Direito Constitucional. Revista de Estudos Politécnicos. Vol VIII (13): 007-018.

Carlsson M, Williams P, Hayes-Conroy J, Lordly D, Callaghan E (2016). School Gardens: Cultivating Food Security in Nova Scotia Public Schools. Canadian Journal of Dietetic Practice and research Vol 77: 119125

Carvalho J, Oliveira F (2016). Classificação Do Solo No Novo Quadro Legal. Almedina. Coimbra. (Classification of land in the new legal framework)

Carvalho R (2017). Introdução Ao Direito Do Urbanismo. Universidade Católica Portuguesa. ( Introduction to urban law) 
Celata F, Coletti R (2018) The Policing of Community Gardening in Rome. Environmental Innovation and Societal Transitions 29: 17-24.

Coleman A (1982) Dead Space in the Dying Inner City. International Journal of Environmental Studies 19(2): 103-7.

Correia F (2008). Manual de Direito Do Urbanismo. 4ạ edição. Coimbra. ( Urban law manual)

Drake L, Lawson L (2013). Validating verdancy or vacancy? The relationship of community gardens and vacant lands in the U.S. Cities: 133-42.

Draus P, Roddy J and Mcduffie A (2013) We don't have no neigbourhood: Advanced marginality and urban agriculture in Detroit. Urban Studies: 1-16.

COE - Conferência Europeia dos Ministros Responsáveis pelo Ordenamento do Território do Conselho da Europa (2011) Glossário de Desenvolvimento Territorial. (European Conference of Ministers responsible for Territorial Planning of the Council of Europe). http://www.dgterritorio.pt/produtos e servicos/publicacoes/outros titulos/glossario do desenvol vimento territorial $5 /$

European Commission (1990). Green Paper on the Urban Environment - Communication from The Commission to The Council and Parliament. http://ec.europa.eu/environment/nature/ecosystems/docs/green infrastructures/1 EN ACT part1 v5.pdf

Fadigas L (2017) O Planeamento Alimentar Nos Instrumentos de Gestão Territorial. Alfaces Na Avenida. $\quad$ http://www.colegiof3.ulisboa.pt/docs/Alfaces na avenidaEstrategias para bem alimentar a cidade-ColegioF3 2017.pdf.

Foo K, Martin D, Wool C and Polsky C (2014) Reprint of The Production of Urban Vacant Land: Relational Placemaking in Boston, MA Neighborhoods. Cities 40: 175-82.

Newman G, Smith A, Brody S (2017) Repurposing Vacant Land through Landscape Connectivity Landscape Journal 36(1): 37-57.

Gomes C (2017). Direito Administrativo Do Ambiente. Tratado de Direito Administrativo Especial.( Adminsitrative environmental law).

Gonçalves R (2014) Hortas Urbanas: Estudo de Caso de Lisboa. https://docplayer.com.br/9476196Hortas-urbanas-estudo-do-caso-de-lisboa-rita-goncalves-galvao-goncalves-dissertacao-para-a-

obtencao-do-grau-de-mestre-em-engenharia-agronomica.html

Gough M, Accordino J (2013) Public Gardens as Sustainable Community Development Partners: Motivations, Perceived Benefits, and Challenges. Urban affairs review. 49(6) $851-887$

Guedes L, (2015) O Porto e Os Seus Planos, Análise Comparativa Do Território Nos Planos Diretores Do Porto e Concelhos Limítrofes. Almedina. (The municipality of Port and its Plans, Comparative Analysis of the Territory in the Master Plans of the Port and Border municipalities).

Hou J, Grohmann D, (2018) Integrating Community Gardens into Urban Parks: Lessons in Planning, Design and Partnership from Seattle. Urban Forestry and Urban Greening 33(May): 46-55. 
Kim G, Miller P, Nowak. D (2018) Urban Vacant Land Typology: A Tool for Managing Urban Vacant Land. Sustainable Cities and Society 36 (October 2017): 144-56. https://doi.org/10.1016/j.scs.2017.09.014.

Krikser T, Piorr A, Berges R, Opitz I (2016) Urban agriculture oriented towards self- supply social and commercial purpose: A typology. Land 5 (28): 1-19

López-goyburu P, García-montero L (2018) The Urban-Rural Interface as an Area with Characteristics of Its Own in Urban Planning : A Review. Sustainable Cities and Society 43(August): 157-65.

Machado C (2014). As Cedências Municipais e o Adequado Crescimento Das Cidades.Almedina. ( The municipalities concessions and the suitable municipality growth)

Madaleno I (2001) Cities of the future: Urban agriculture in the third millennium.FNA- ANA. 29:14-21

McClintock N,Cooper J, Khandeshi S (2013) Assessing the Potential Contribution of Vacant Land to Urban Vegetable Production and Consumption in Oakland, California. Landscape and Urban Planning 111: 46-58.

Moragues-Faus A, Morgan K (2015) Reframing the foodscape: the emergent world of urban food policy. Environment and Planning A. Vol. 47:1558-1573

Moreira M, Almeida T, Mourão I, Brito M (2017) I Colóquio Nacional de Horticultura Social e Terapêutica. Relação Entre Bem - Estar e a Utilização de Hortas Urbanas Biológicas. (Relationship Between Well-Being and the Use of Organic Urban Gardens) http://www.aphorticultura.pt/uploads/4/8/0/3/48033811/actas-portuguesas-horticultura-n27-aphjul17.pdf

Nassauer J, Raskin J (2014) Urban Vacancy and Land Use Legacies: A Frontier for Urban Ecological Research, Design, and Planning. Landscape and Urban Planning 125: 245-53.

Németh J, Langhorst J (2014) Rethinking Urban Transformation: Temporary Uses for Vacant Land. Cities 40: 143-50.

Newman G, Bowman A, Lee R, Kim B (2016) A Current Inventory of Vacant Urban Land in America Journal of Urban Design 21(3): 302-19.

Oliveira F (2002) Direito do Ordenamento do Território. Cadernos CEDOUA. ( Territorial planning law)

Oliveira F (2015). Notas e Comentários à Revisão Do Regime Jurídico Dos Instrumentos de Gestão Territorial de 2015. Almedina. (Notes and Comments on the Revision of the Legal Framework of Territorial planning Instruments of 2015).

Oliveira F (2016) Regime Juridico Dos Instrumentos de Gestão Territorial. Decreto - Lei n.o 80/2015, de 14 de Maio. Comentado. ( Legal Regime of Territorial Planning Instruments)

OLiveira F (2017). Escritos Práticos de Direito Do Urbanismo. Almedina.(Practical Writings of Urban Planning Law).

Olveira F (2018) Direito Do Urbanismo. Do Planeamento à Gestão. ed. Associação de Estudos de Direito Regional e Local. (Urban Law)

Pagano M, Bowman A (2000) Vacant Land in Cities: An Urban Resource: 1-9. 
Park K, Ciorici P ( 2013) Determinants of Vacant Lot Conversion into Community Gardens : Evidence from Philadelphia. International Journal of Urban Sciences 17(3): 385-98.

Pereira A, (2017) Proposta de Implementação de Uma Rede de Hortas Urbanas Na Cidade Do Porto. Tesis ( UTAD)

Pinto R, (2011) Viabilidade Ambiental das Hortas Urbanas enquanto Espaços para o Desenvolvimento Sustentável. Tesis. Universidade de Coimbra.

PNPOT. 2018. http://pnpot.dgterritorio.pt/pnpot

Pothukuchi K (2018) Vacant Land Disposition for Agriculture in Cleveland, Ohio: Is Community Development a Mixed Blessing ? Journal of Urban Affairs 40(5): 657-78.

Programme, United Nations Human Settlements UNHS (2015). International Guidelines on Urban and Territorial Planning. https://unhabitat.org/books/international-guidelines-on-urban-and-territorialplanning/

Quintas A (2014) Génese e Evolução dos modelos de estrutura verde urbana na estratégia de desenvolvimento das cidades. A obra nasce 8: 153-167

Sanches P, Pellegrino P (2016) Greening Potential of Derelict and Vacant Lands in Urban Areas. Urban Forestry and Urban Greening 19: 128-39.

Saraiva R (2012) A Juricidade Do Princípio Do Desenvolvimento Sustentado. IV Jornadas Do Ambiente, Energias e Alterações Climáticas https://www.ua.pt/idad/PageText.aspx?id=16235

Schukoske J (2000) Community development through gardening: state abd local policies transforming urban open space. Legislation and Public Policy: 351-92.

Shaw D, Crossan J, Cumbers A, McMaster R, Trebeck K, Black I(2016) Places of presumption: Community gardens putting the "we" into neighborhoods. Families, Relationships and Societies. Vol 5 (3): 473-479

Smith J, Li X,Turner II B (2017) Lots for Greening : Identification of Metropolitan Vacant Land and Its Potential Use for Cooling and Agriculture in Phoenix , AZ , USA. Applied Geography 85: 139-51.

Sotelo P (2017) At Home in Inner-City Immigrant Community Gardens. Journal of Housing and the Built Environment. Volume 32 (1):13-28

Sottile F, Fiorito D, Tecco N, Girgenti V (2016) An Interpretive Framework for Assessing and Monitoring the Sustainability of School Gardens. Sustainability 8 (801): 1-15

Sousa D, Madureira H (2017) Padrões Territoriais Da Agricultura Urbana Na Cidade Do Porto." GOT Journal of Geography and Spatial Planning 1(11): 309-25.

Telles G (1996) Um Novo Conceito de Cidade: A Paisagem Global.( A New City Concept: The Global Landscape).

Tornaghi C (2014) Critical geography of urban agriculture. Progress in Human Geography. Vol. 38(4) 551-567 
Trigo S (2006) Understanding Urban Vacant Land : A Way Towards Resilient Urban Fabrics .1-7

Truong S, Gray T, Ward K ( 2016) Sowing and growing" life Skills through garden- based learning to reengage disengaged youth. Learning Landscapes: 361-85.

Turner B, Henryks J, Pearson D (2011) Community gardens: sustainability, health and inclusion in the city. Local environment Vol. 16 (6): 489-492

Ultramari C, Oliveira R, Meister G (2018) Idealizing Brazilian Cities: Their Master Plans from 1960 through 2015. Cities 83: 186-92.

United Nations World Commission on Environment and Development. 1987. "Brundtland Report: Our Common Future." United Nations. http://www.un-documents.net/our-common-future.pdf.

Viljoen A (2005). Continuous Productive Urban Landscapes. http://library.uniteddiversity.coop/Food/Continuous Productive Urban Landscapes.pdf

Wong R, Gable L, Rivera Z (2018) Perceived Benefits of Participation and Risks of Soil Contamination in St. Louis Urban Community Gardens. Journal of Community Health 43(3): 604-10.

Legislation:

Law from 2014 (Portuguese Parliament 2014) Law no.31/2014, of May 30th

Law decree from 2015 (Portuguese Government 2015) Law decree no. 80/2015, of May 14th

Regulatory Decree (Portuguese Government 2015) Regulatory Decree No. 15/2015 of August 19th.

Law decree from 2015 (Portuguese Government 2015) Law decree no 4/2015 of January $7^{\text {th }}$.

Constitutional Law 1976 (Portuguese Parliament 1976) 